\title{
Temperature-dependent development and somatic growth in two allopatric populations of Acartia clausi (Copepoda: Calanoida)
}

\author{
Sérgio Miguel Leandro ${ }^{1, *}$, Henrique Queiroga ${ }^{1}$, Laura Rodríguez-Graña ${ }^{2}$, \\ Peter Tiselius $^{3}$ \\ ${ }^{1}$ Department of Biology, University of Aveiro, Campus Universitário de Santiago, 3810-193 Aveiro, Portugal \\ ${ }^{2}$ Departamento de Ecología, Facultad de Ciencias, Universidad de la República, Iguá 4225, Montevideo, Uruguay \\ ${ }^{3}$ Göteborg University, Department of Marine Ecology, Kristineberg Marine Research Station, 45034 Fiskebäckskil, Sweden
}

\begin{abstract}
This study compares the effect of temperature on the post-embryonic development time and weight-specific growth rate in 2 populations of Acartia clausi from different biogeographic areas (northern and southern Europe). Development was followed from nauplius I to adult at 3 temperatures $\left(10,15\right.$ and $\left.18^{\circ} \mathrm{C}\right)$ at saturating food conditions. The relationship between development time and temperature was established by fitting Belehradek's function. The northern population had a shorter generation time at all temperatures. At $10^{\circ} \mathrm{C}$, the development time was estimated to be 33.9 and $36.4 \mathrm{~d}$ decreasing to 16.3 and $17.4 \mathrm{~d}$ at $18^{\circ} \mathrm{C}$ for the northern and southern populations, respectively. Prosome length decreased with temperature, and the southern population had longer individuals at all temperatures. ANCOVA revealed a significant $(p<0.001)$ positive effect of temperature on the growth rates, and nauplii grew faster than copepodites (except at $18^{\circ} \mathrm{C}$ in the southern population and $20^{\circ} \mathrm{C}$ in the northern population). Significant differences between populations were noted during larval growth, with nauplii from the north growing faster at high temperatures $\left(18^{\circ} \mathrm{C}\right)$. The results indicate that the $2 \mathrm{~A}$. clausi allopatric populations subjected to different temperature regimes have different temperature responses, in particular at high temperatures.
\end{abstract}

KEY WORDS: Temperature $\cdot$ Development time $\cdot$ Weight-specific growth rate $\cdot$ Acartia clausi $\cdot$ Ria de Aveiro (Portugal) · Gullmarsfjord (Sweden)

\section{INTRODUCTION}

Temperature is an important environmental factor for ectotherm organisms like copepods, and it strongly affects vital physiological rates, such as respiration (e.g. Roddie et al. 1984, Gaudy et al. 2000) and excretion (e.g. Gaudy et al. 2000). Along with food conditions, temperature can also modify the life-history traits of copepods through its influence on mortality rates (e.g. Hirst \& Kiørboe 2002), egg production (e.g. Halsband-Lenk et al. 2002) and growth and development rates (Campbell et al. 2001, Hirst \& Kiørboe 2002).
Calanoid copepods often dominate the zooplankton in terms of abundance and biomass, and some species occur over wide biogeographic regions (Mauchline 1998). The neritic copepod Acartia clausi Giesbrecht has been recorded in different areas of the Atlantic Ocean, such as the North Sea (Tiselius et al. 1991), Irish Sea (Castellani \& Lucas 2003), English Channel (Lindley et al. 1997), Cantabrian coast (Quevedo et al. 1999) and northwest coast of Portugal (Morgado et al. 2003) as well as in other areas including the Mediterranean Sea (Gaudy et al. 2000), Black Sea (Gubanova et al. 2002), Gulf of Guinea (Pagano et al. 2003) and Pacific Ocean (Gomez-Gutierrez et al. 1999). 
The populations are subjected to local conditions, creating site-specific adaptations and eventually genetic differences. Reduced gene flow between populations will over time create different genotypes. The degree of genetic exchange between populations depends on the capacity that a given sub-population has to remain and keep isolated in a given area. Acartia spp. species are common in extremely advective regions, such as coastal areas and estuaries, but can establish persistent populations. A. clausi is able to maintain isolated populations even at relatively short spatial scales, in contrast to other species such Calanus spp. (Bucklin et al. 2000).

The retention of Acartia spp. populations in a given region may be attributed to the combined effect of the swimming behaviour that allows regulation of vertical distribution (Kouassi et al. 2001); the production of diapause eggs (Castro-Longoria 2001) in response to unfavourable environmental conditions; and life-history traits such as short generation times and high reproductive potential. The evidence that genetic differences occur among allopatric populations of A. clausi implies that population-specific responses to environmental conditions could exist.

The present study was aimed at comparing the effects of temperature on the development and growth rate of 2 populations of Acartia clausi from northern $\left(58^{\circ} 15^{\prime} \mathrm{N}, 11^{\circ} 27^{\prime} \mathrm{E}\right)$ and southern Europe $\left(40^{\circ} 38^{\prime} \mathrm{N}\right.$, $8^{\circ} 44^{\prime} \mathrm{W}$ ). The southern population (Ria de Aveiro, Portugal) experiences a temperature range of 11 to $20^{\circ} \mathrm{C}$ and shows abundance peaks in July and October, when water temperature varies from 17 to $20^{\circ} \mathrm{C}$ (S. M. Leandro unpubl.). The northern population (Gullmarsfjord, Sweden) lives where the water temperature fluctuates between -1 and $20^{\circ} \mathrm{C}$ and is most abundant from June to August $\left(14\right.$ to $20^{\circ} \mathrm{C}$, Eriksson 1973). Our null hypothesis was that development time and growth rates of the 2 populations were not different when reared at the same temperature. To test this, development was followed from nauplius I to adults at 3 temperatures $\left(10,15\right.$ and $\left.18^{\circ} \mathrm{C}\right)$ and at saturating food conditions.

\section{MATERIALS AND METHODS}

Parental cultures. In order to avoid confounding effects of field temperature on development and growth, all copepods for the parental cultures were collected at nearly the same water temperature $\left(16^{\circ} \mathrm{C}\right)$, but at different seasons for the northern and southern populations. Accordingly, Acartia clausi were collected in the Gullmarsfjord, Sweden $\left(58^{\circ} 15^{\prime} \mathrm{N}, 11^{\circ} 27^{\prime} \mathrm{E}\right.$, northern population), in summer of 2002 and in Ria de Aveiro, Portugal $\left(40^{\circ} 38^{\prime} \mathrm{N}, 08^{\circ} 43^{\prime} \mathrm{W}\right.$, southern population) in spring 2003. We did not replicate the sampling of parental animals but studied the temperature response within each population, represented by a single subsample. Although genetic differences can occur over short distances (Bucklin et al. 2000), the sampling areas are highly dynamic and the populations continuously reproducing, and we assumed that sampling several thousand females on 1 occasion would give a good representation of the population in the area.

The copepods were caught with horizontal tows at $2 \mathrm{~m}$ using a $200 \mu \mathrm{m}$ mesh net fitted with a 101 plastic bag as a cod end. After collection, the samples were diluted in surface water and brought to the laboratory within $1 \mathrm{~h}$. In the laboratory, ca. 2000 females of Acartia clausi from each location were sorted out using a binocular microscope and transferred to 201 buckets. The animals were fed with a mixture of the diatom Thalassiosira weissflogii (equivalent spherical diameter, ESD $=14.5 \mu \mathrm{m}$ ) and the cryptophyte Rhodomonas sp. (ESD $=6.7 \mu \mathrm{m})$. The microalgae were grown in $\mathrm{f} / 2$ medium (Guillard 1962) at $20^{\circ} \mathrm{C}$ under a $12: 12 \mathrm{~h}$ light:dark cycle. Both algal strains were provided by the Marine Algal Culture Centre at Göteborg University (GUMACC).

Eggs from the field-caught females were harvested daily, rinsed in filtered seawater and stored in $10 \mathrm{ml}$ plastic tubes at $4^{\circ} \mathrm{C}$ in the dark. Parental stock cultures for the northern and southern populations were subsequently started with the eggs collected from the corresponding field culture and placed in 401 carboys containing filtered seawater $(<0.2 \mu \mathrm{m}$, salinity $32 \mathrm{psu})$ and maintained at $18^{\circ} \mathrm{C}$. The cultures were fed Rhodomonas sp. ad libitum during naupliar development and a mixture of Rhodomonas sp. and Thalassiosira weissflogii after the appearance of copepodites.

Growth experiments. Growth experiments started after the parental cultures were acclimated for 1 generation (Table 1). For each treatment/replicate $\sim 10000$ eggs were harvested from the corresponding stock and

Table 1. Acartia clausi. Experiments performed. Ambient temperature, date of collection of the field populations, end of acclimation period and dates for each experiment. Eggs for experiments were stored at $4^{\circ} \mathrm{C}$ in the dark from end of acclimation to start of experiments

\begin{tabular}{|lcc|}
\hline & Northern & Southern \\
\hline Ambient temperature $\left({ }^{\circ} \mathrm{C}\right)$ & 16.8 & 15.6 \\
Date of collection & 19 Jul 2002 & 24 Feb 2003 \\
End of acclimation & 20 Aug 2002 & 25 Mar 2003 \\
Start of experiments & & \\
$10^{\circ} \mathrm{C}$ & 06 Sep 2002 & 29 Mar 2003 \\
$15^{\circ} \mathrm{C}$ & 27 Aug 2002 & 31 Mar 2003 \\
$18^{\circ} \mathrm{C}$ & 06 Sep 2002 & 29 Mar 2003 \\
$20^{\circ} \mathrm{C}$ & 27 Aug 2002 & - \\
$22^{\circ} \mathrm{C}$ & - & 31 Mar 2003 \\
\hline
\end{tabular}


transferred to polyethylene buckets containing 101 of filtered seawater $(<0.2 \mu \mathrm{m}$, salinity $32 \mathrm{psu})$ with gentle aeration. The eggs were collected from the bottom of the 'parental culture' by sieving through successive nylon screens with 200, 90 and $75 \mu$ meshes in order to exclude adults, copepodites, nauplii and faecal pellets. The fraction collected on the $75 \mu \mathrm{m}$ sieve was then transferred to a small Petri dish and concentrated to the centre by slow rotating movements and further cleaned by removing early nauplius and detritus. For both populations, each treatment/replicate was set up at the same time. The growth experiments were performed in duplicate at 10,15 and $18^{\circ} \mathrm{C}$ with each population. In addition, 1 experiment at $20^{\circ} \mathrm{C}$ with the northern population and 2 experiments at $22^{\circ} \mathrm{C}$ with the southern population were performed. All experiments were carried out in a temperature-controlled room, under a 12:12 h light:dark cycle. Food levels were always $\geq 1000 \mu \mathrm{g} \mathrm{C} \mathrm{l}^{-1}$, which is 3 times higher than the optimal food concentration previously defined for Acartia clausi (Klein Breteler \& Schogt 1994). The food offered was Rhodomonas sp. during naupliar growth (NI to NVI) and a mixture of Rhodomonas sp. and Thalassiosira weissflogii during the copepodite stages (I to VI). Food concentration was checked daily by an electronic particle counter (Elzone 180XY). Algal biovolume $\left(\mu \mathrm{m}^{3}\right)$ was converted to carbon using the relationship defined by Strathmann (1967). The food concentration was adjusted daily by adding fresh culture and always kept $\geq 1000 \mu \mathrm{g} \mathrm{C} \mathrm{l}^{-1}$.

Stage duration. The development was followed from Stage NI to the adult stage. Time 0 was defined as the time when eggs were harvested (eggs 0 to $24 \mathrm{~h}$ old) and incubation started. Each experiment was sampled daily by mixing the bucket and sieving 100 to $300 \mathrm{ml}$ of water to yield at least 30 individuals for stage determination and length measurements. Total volume of the bucket was kept constant by adding filtered seawater.

The duration of each development stage (stage duration, SD) was calculated as the difference of the median development time (MDT) of 2 successive stages. The MDT of a certain stage was defined as the time when $50 \%$ of the organisms in a culture had passed that stage (Landry 1975b, 1983), which in turn was estimated from stage-frequency data converted to stage proportion. The cumulative proportion of each stage over time was plotted against time and a gamma distribution function fitted (Klein Breteler et al. 1994). The relationship between temperature and median development time (from egg to adult) of each population was estimated using Belehradek's function:

$$
D=a(T+C)^{-2.05}
$$

where $D$ is median development time (days), $T$ is temperature $\left({ }^{\circ} \mathrm{C}\right)$ and $a$ and $C$ are fitted coefficients
(McLaren 1995). The coefficients were estimated by non-linear regression using the software Statistica 6.0.

Body-length and weight measurements. Total body length of nauplii $(\mu \mathrm{m})$ and prosome length of copepodites $(\mu \mathrm{m})$ were measured with an inverted microscope (100× magnification) with a calibrated eyepiece micrometer. Prosome lengths up to Stage CIII were compared by 2-way ANOVA (population and temperature as factors) and when sexes were discerned (CIV to adults) by 3-way ANOVA (sex, population and temperature as factors). The weight of nauplii (NI to NVI) was estimated from a length-weight regression (Hay et al. 1991). For each copepodite stage at each temperature and population, 10 to 20 individuals were rinsed briefly with distilled water and placed in pre-weighed small aluminium caps. After $24 \mathrm{~h}$ at $60^{\circ} \mathrm{C}$, the dry weight was measured on a microbalance (Mettler Toledo, sensitivity $1 \mu \mathrm{g}$ ).

Weight-specific growth rates. The body weight of each developmental stage (natural-logarithm transformed) was plotted against cumulative time for each temperature and population, separating nauplii and copepodites. Each data set was then fitted to a linear regression where the slope represents the growth rate $\left(g, \mathrm{~d}^{-1}\right)$. The effects of population (northern and southern), growth phase (nauplii and copepodites) and temperature on growth rate were analyzed through an ANCOVA, where the natural logarithm of dry weight (lnDW) was the dependent variable, development time (days) the covariate and population, growth phase and temperature the independent factors. The relationship between $g$ and temperature was described by a nonlinear regression assuming that individuals grow exponentially (Huntley \& Lopez 1992, Mauchline 1998).

\section{RESULTS}

Stage duration decreased significantly with temperature for both populations (Fig. 1, Table 2). Nearly isochronal growth, with similar stage durations through the late naupliar stages (NIII to NVI) and early copepodite stages (CI to CIII), was noted for both populations (Table 2). The Stage NI was always shorter and Stage NII longer than other naupliar stages. Stage duration tended to increase with age. The estimated generation times equalled 33.9, 20.8 and $16.3 \mathrm{~d}$ for the northern population and $36.4,22.3$ and $17.4 \mathrm{~d}$ for the southern population at 10,15 and $18^{\circ} \mathrm{C}$, respectively. For each population, the relationship between temperature and generation time was fitted to Belehradek's function (Fig. 2).

The prosome length of all copepodites was longer in the southern population than in the northern population, and prosome length decreased with tempera- 

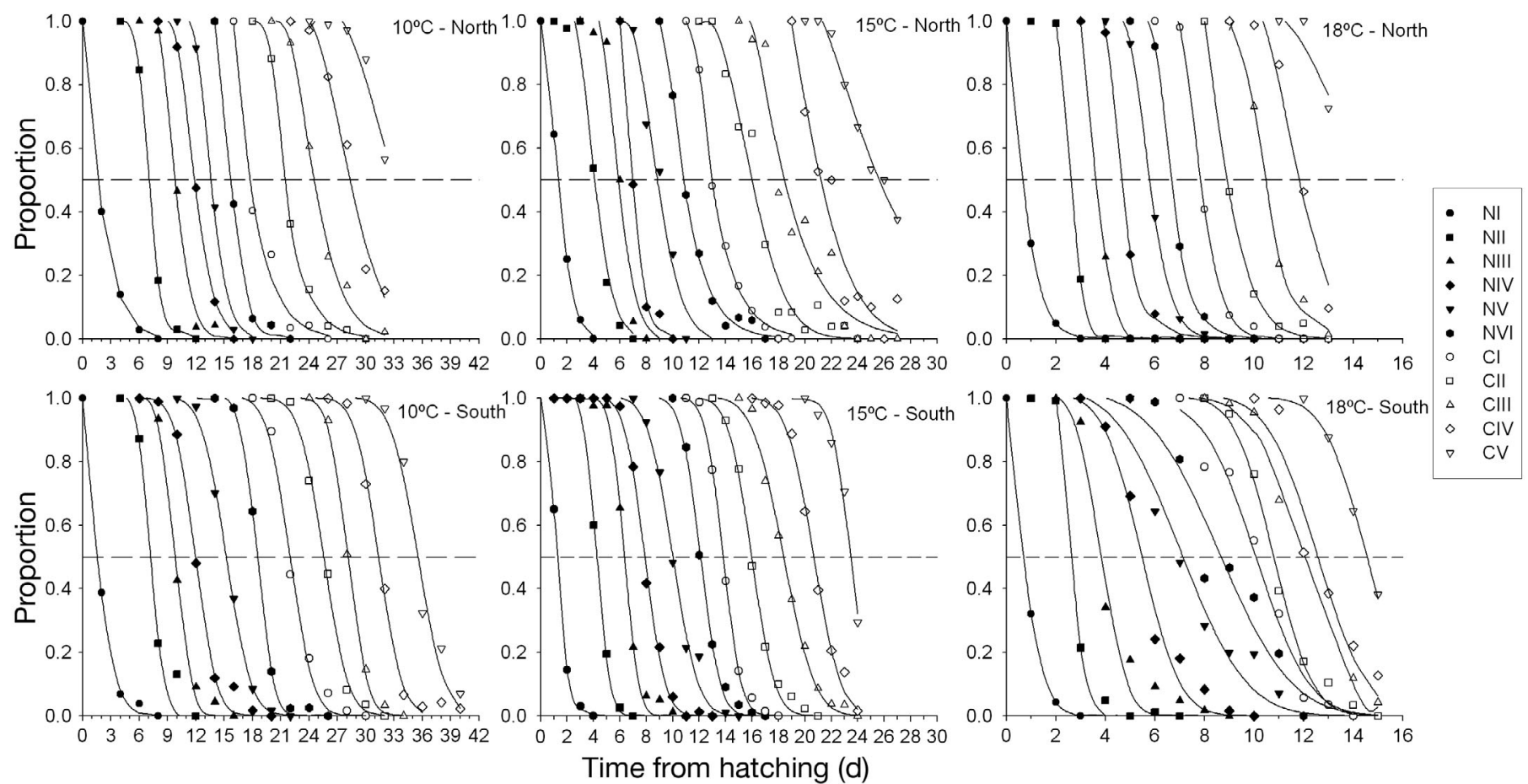

Fig. 1. Acartia clausi. Post-embryonic development time for the northern and southern populations reared at 10,15 and $18^{\circ} \mathrm{C}$. For each development stage, a gamma distribution was fitted to the cumulative proportions plotted against time. The intersection between the dashed line (=50\%) and the fitted Gamma function defines the mean development time (MDT) for the particular stage

ture (Fig. 3). Both effects were significant (2-way ANOVA, $\mathrm{p}<0.001)$. The effect of sex (CIV to CVI) was also highly significant (3-way ANOVA, $\mathrm{p}<0.001)$, with females always being longer than males. The length ratio of successive stages was nearly constant in both populations, 1.22 (southern) and 1.20 (northern). A length-weight regression for all copepodite stages and adults (both populations pooled) was estimated:

$$
\log \mathrm{DW}=2.064 \log \mathrm{PL}-5.080 \quad\left(\mathrm{r}^{2}=0.846, \mathrm{p}<0.001\right)
$$

where DW is dry weight $(\mu \mathrm{g})$ and PL prosome length $(\mu \mathrm{m})$.
The weight-specific growth rate $\left(g, \mathrm{~d}^{-1}\right)$ was estimated separately for each temperature and population (Fig. 4) from the slopes of the linear regression of $\operatorname{lnDW}$ on cumulative development time. The parameter estimates of the regressions are given in Table 3. An ANCOVA testing for the homogeneity of slopes among the regression lines (Table 4) indicated that for both populations and within a given temperature range, nauplii grew significantly faster than copepodites (ANCOVA homogeneity of slopes, stage $\times$ covariate). Exceptions to this rule were noted at $18^{\circ} \mathrm{C}$ for the southern population and at $20^{\circ} \mathrm{C}$ for the northern pop-

Table 2. Acartia clausi. Stage duration (d) of northern and southern populations estimated at 5 temperatures $\left({ }^{\circ} \mathrm{C}\right)$ and under saturating food conditions $\left(\geq 1000 \mu \mathrm{g} \mathrm{C}^{-1}\right)$. Mean value $( \pm \mathrm{SE}), \mathrm{n}=2$; where no $\mathrm{SE}$ is given, $\mathrm{n}=1$. Experiments at 20 and $22^{\circ} \mathrm{C}$ were not performed on both populations

\begin{tabular}{|lccccccccccc}
\hline Temp. & \multirow{2}{*}{ NI } & NII & NIII & NIV & NV & NVI & CI & CII & CIII & CIV & CV \\
\hline Northern & & & & & & & & & & \\
10 & $2.0 \pm 0.39$ & $5.9 \pm 0.71$ & $2.6 \pm 0.40$ & $2.2 \pm 0.12$ & $2.2 \pm 0.50$ & $2.4 \pm 0.15$ & $2.3 \pm 0.39$ & $3.5 \pm 0.13$ & 3.3 & 3.8 & 4.7 \\
15 & $1.5 \pm 0.20$ & $3.2 \pm 0.35$ & $2.0 \pm 0.31$ & $1.5 \pm 0.40$ & $1.9 \pm 0.03$ & $2.3 \pm 0.37$ & 2.2 & 3 & 2.4 & 2.8 & 4.5 \\
18 & $0.7 \pm 0.04$ & $1.9 \pm 0.01$ & $1.1 \pm 0.17$ & $0.9 \pm 0.16$ & $1.2 \pm 0.02$ & $0.8 \pm 0.05$ & $1.2 \pm 0.02$ & $1.1 \pm 0.05$ & $1.4 \pm 0.06$ & $1.5 \pm 0.01$ & $2.8 \pm 0.17$ \\
20 & 1.4 & 2.6 & 1 & 0.7 & 0.7 & 1 & 1 & 0.9 & 1.6 & 0.7 & 1.5 \\
Southern & & & & & & & & & & & \\
10 & $1.4 \pm 0.07$ & $5.4 \pm 0.05$ & $2.9 \pm 0.15$ & $1.9 \pm 0.25$ & $3.4 \pm 0.16$ & $3.4 \pm 0.04$ & $3.3 \pm 0.08$ & $3.9 \pm 0.25$ & $2.9 \pm 0.25$ & $3.4 \pm 0.18$ & $4.4 \pm 0.19$ \\
15 & $1.2 \pm 0.00$ & $3.0 \pm 0.01$ & $2.1 \pm 0.02$ & $1.5 \pm 0.00$ & $2.1 \pm 0.00$ & $2.1 \pm 0.00$ & $1.7 \pm 0.01$ & $2.2 \pm 0.02$ & $2.4 \pm 0.01$ & $2.3 \pm 0.02$ & $2.9 \pm 0.01$ \\
18 & $0.7 \pm 0.03$ & $2.1 \pm 0.24$ & $1.4 \pm 0.23$ & $1.6 \pm 0.08$ & $1.4 \pm 0.06$ & $1.9 \pm 0.17$ & $1.5 \pm 0.09$ & $1.0 \pm 0.21$ & $1.3 \pm 0.19$ & $1.5 \pm 1.07$ & $1.4 \pm 0.82$ \\
22 & $0.4 \pm 0.16$ & $2.1 \pm 0.28$ & $1.3 \pm 0.28$ & $1.0 \pm 0.08$ & $1.2 \pm 0.03$ & $1.0 \pm 0.04$ & $1.4 \pm 0.11$ & $1.0 \pm 0.02$ & $1.2 \pm 0.05$ & $1.1 \pm 0.02$ & $1.9 \pm 0.03$ \\
\hline
\end{tabular}




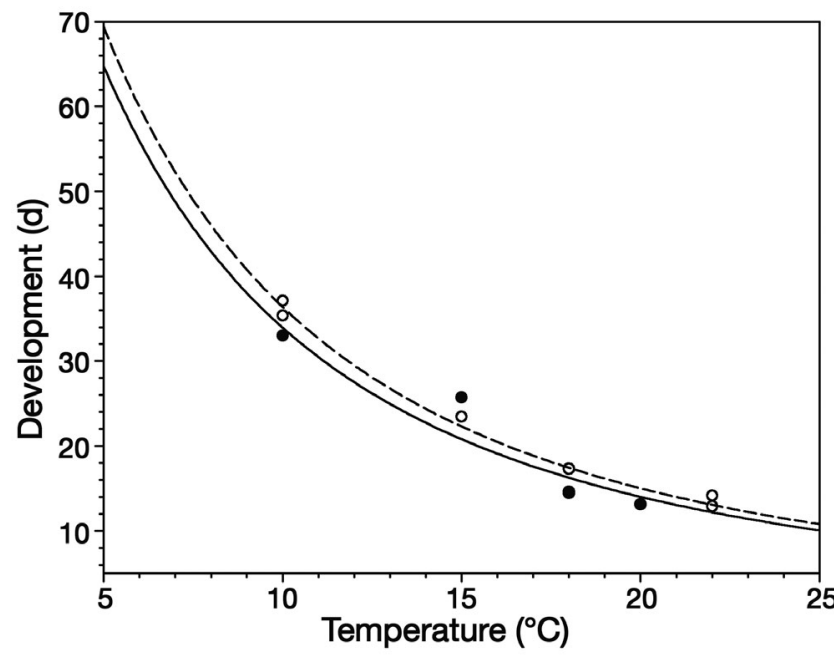

Fig. 2. Acartia clausi. Relationship between temperature (T) and generation time $(D)$ for the northern (solid symbols) and southern (open symbols) populations. The estimated parameters of Belehradek's function were: $D=13490.3(T+8.53)^{-2.05}$ $\left(\mathrm{r}^{2}=0.897, \mathrm{p}<0.01\right.$; solid line) for the northern population, and $D=14410.4(T+8.50)^{-2.05}\left(\mathrm{r}^{2}=0.978, \mathrm{p}<0.001\right.$; dashed line) for the southern population

ulation. Growth rates of nauplii and copepodites of both populations also increased significantly with temperature (ANCOVA homogeneity of slopes, temperature $\times$ covariate) .

The effect of population was evaluated separately for nauplii and copepodites (within temperature and stage, effect of population). Nauplii from the northern population grew faster than the ones from the southern population, but only at the highest temperature $\left(18^{\circ} \mathrm{C}\right)$.
No significant differences between the growth rates of copepodites from the northern and southern populations were found. The weight-specific growth rate $(g)$ for both nauplii and copepodites of the Acartia clausi populations could be compared using the Huntley \& Lopez (1992) equation:

$$
g=a \mathrm{e}^{(b T)}
$$

where $T$ is temperature $\left({ }^{\circ} \mathrm{C}\right)$ and $a$ and $b$ are fitted constants.

The temperature-dependent growth models adjusted for nauplii and copepodites from each population are shown in Fig. 5. The northern population increased growth by 8 to $13 \%{ }^{\circ} \mathrm{C}^{-1}$ increase in temperature, whereas the southern population only increased growth by 7 to $8 \%{ }^{\circ} \mathrm{C}^{-1}$.

\section{DISCUSSION}

The aim of this study was to evaluate the importance of temperature on the development and growth rate of 2 allopatric populations. In the experimental design we therefore kept several other critical parameters constant, such as salinity, food and light:dark cycle. Although the 2 populations can (and probably do) encounter different food conditions in the field, this has been found to affect fecundity of adult females more than somatic growth of other stages (Hirst \& Bunker 2003). We cannot exclude that other factors may be more important or that synergistic effects do not exist, but we will only discuss the factor manipulated in the study, temperature.

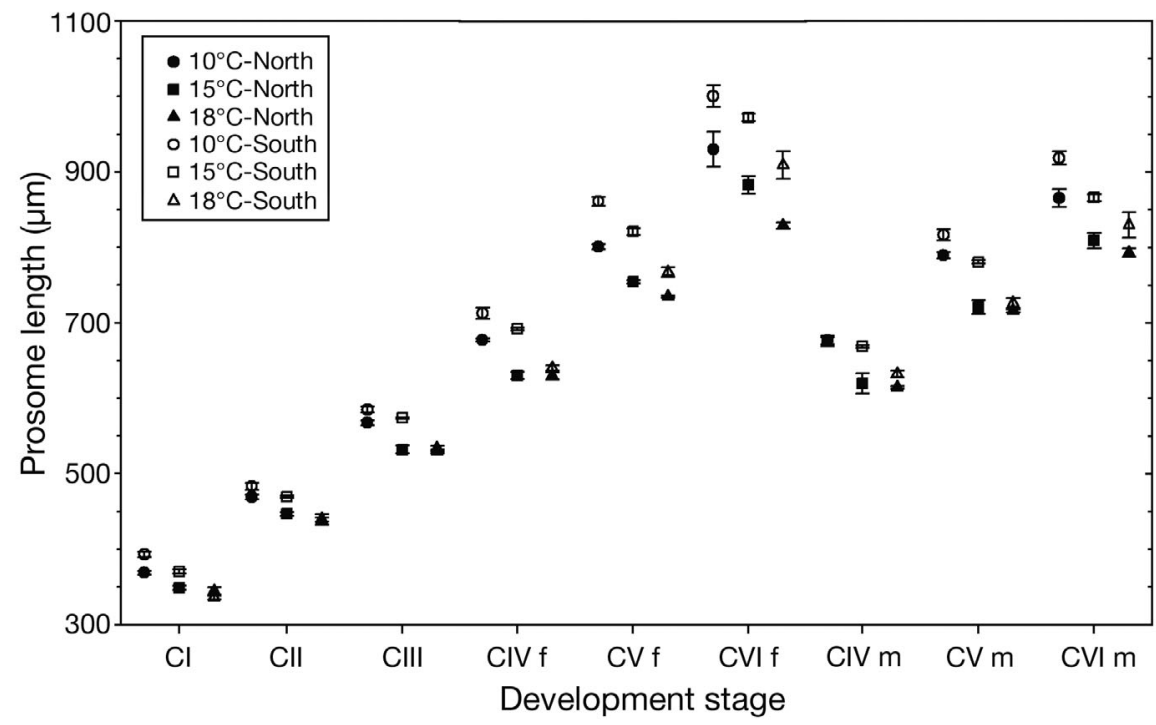

Fig. 3. Acartia clausi. Mean prosome lengths of copepodites (CI-CVI, males and females separated from CIV) from the 2 populations. Error bars represent SE

\section{Stage durations}

Isochronal development (Miller et al. 1977, Landry 1983) states that, for a given species, the time spent in each developmental stage is the same for all stages (Peterson 2001). We observed a nearly isochronal development of Stages NIII to CIII. A common feature at all temperatures was the relatively short duration of the first naupliar stage. This stage does not feed, but uses lipid reserves to fuel growth. In contrast, 2 stages showed a longer development, NII (first feeding stage) and CV (stage just prior to adult). During Stage NII the animal develops a digestive tract and a foraging behaviour, and a similar prolonged duration has been found in both Acartia clausi (Landry 


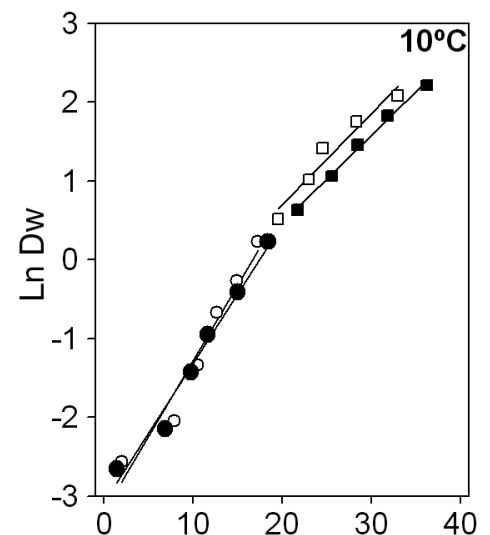

- Nauplii - South
- Copepodites - South
- Nauplii - North
- Copepodites - North
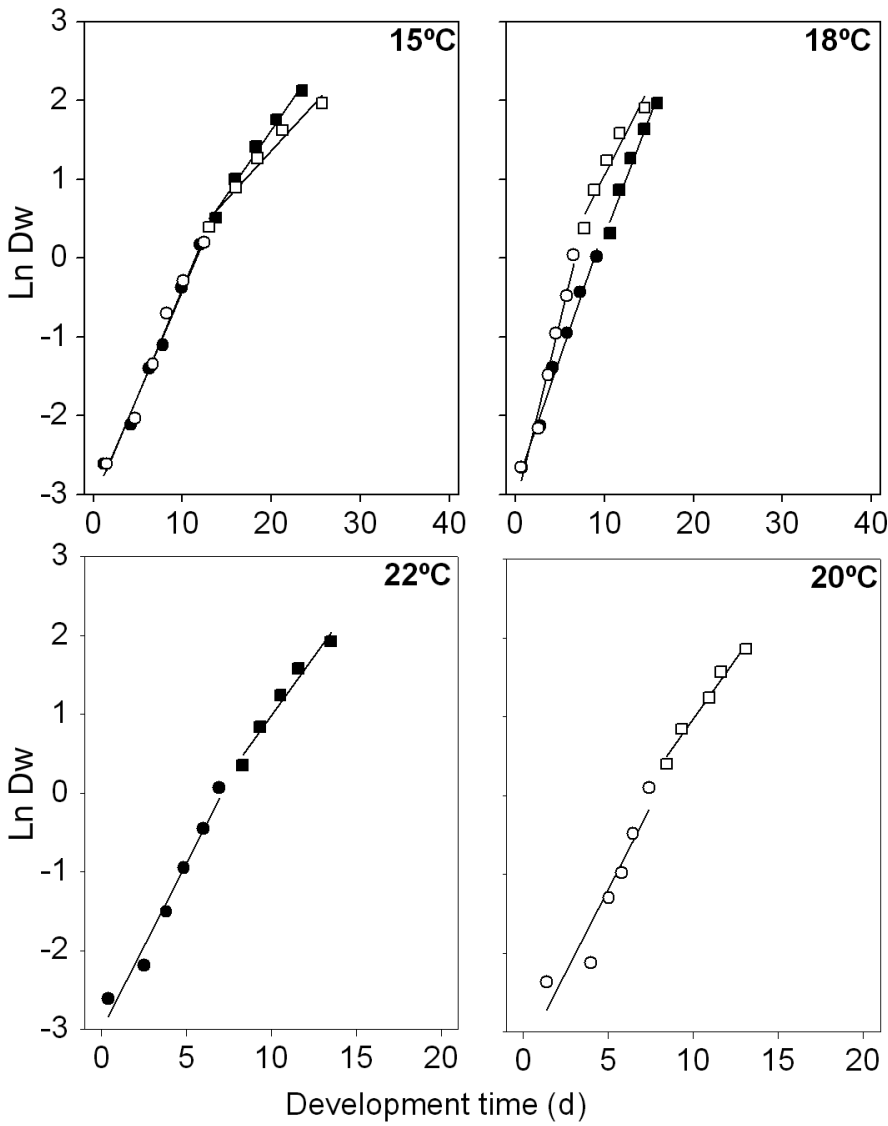

Fig. 4. Acartia clausi. Linear regressions of ln-transformed body weight $(\mu \mathrm{g})$ on cumulative development time (d) for each temperature and population. Nauplii and copepodites are separated and parameter estimates for each regression are given in Table 3

1975b) and Acartia tonsa (Berggreen et al. 1988). The increased duration of Stage CV corresponds to the transition to adult males and females during which the animal undergoes external morphological differentiation and sexual maturation (Landry 1983, Peterson 2001). We did not estimate the development time for males and females separately, but it is known that males develop faster than females (Landry 1983). Thus, a significant proportion of duration of Stages CIV and CV is due to to the development of the females. Deviations from the isochronal pattern of development are not limited to Acartia spp.; they have been noted in other species, such as Paracalanus parvus (Landry 1983), Pseudocalanus elongatus (Klein Breteler et al. 1995) and Calanus finmarchicus (Campbell et al. 2001).

\section{Development times versus temperature}

The 2 allopatric populations of Acartia clausi were exposed to different temperature regimes in the field, with the northern population living at lower temperatures, but also experiencing a wider range of temperatures, -1 to $20^{\circ} \mathrm{C}$ versus 11 to $20^{\circ} \mathrm{C}$ in the southern population. The northern population had a shorter generation time, even at higher temperatures, than it normally experiences in the field. A strong response to changes in temperature can be selected for if the temperature range experienced by the population is wide. The selection of fast-growing animals in the colder environment could have resulted in different genotypes with specific temperature responses. During juvenile development and growth, the cold-acclimated organisms had a stronger response to temperature than warm-acclimated ones. A similar response to high temperatures has been reported for egg development in A. clausi (Landry 1975a,b).

With decreasing temperature, the southern population showed a gradual delay in development compared with the northern population, and the largest difference $(2.5 \mathrm{~d})$ occurred at $10^{\circ} \mathrm{C}$. This delay could be due to depressed metabolic rates at the lower limit of its thermal range, indicating that the optimum temperature of each population is different. The lower limit of the southern population would occur at higher temperatures than for the northern population.

\section{Body size}

Phenotypic plasticity (Atkinson 1994) was exhibited by individuals of both populations when reared at different temperatures. The ontogenetic response to temperature was an increased body length with the decreasing temperature. Increase in size and slow development at low temperatures are common in several marine copepods species. A corresponding shortening of the life cycle at high temperatures would allow a population to take advantage of favourable environmental conditions, by growing faster and achieving maturity earlier (Atkinson 1994). In addition, 
Table 3. Acartia clausi. Parameter estimates for linear regressions in Fig. 4 and respective significance. Regressions are of the form $\operatorname{lnDW}=a+b D$, where the slope $(b)$ represents the weight-specific growth rate $\left(\mathrm{d}^{-1}\right), \mathrm{DW}$ is the dry weight $(\mu \mathrm{g})$ and $D$ the development time (d) (N - nauplii, C-copepodites)

\begin{tabular}{|lcccccc|}
\hline $\begin{array}{l}\text { Temp. } \\
\left({ }^{\circ} \mathrm{C}\right)\end{array}$ & $\begin{array}{c}\text { Popu- } \\
\text { lation }\end{array}$ & Stage & $a$ & $b$ & $\mathrm{r}^{2}$ & $\mathrm{p}$ \\
\hline 10 & Northern & $\mathrm{N}$ & -3.197 & 0.192 & 0.958 & $<0.001$ \\
& & $\mathrm{C}$ & -1.616 & 0.116 & 0.949 & $<0.001$ \\
& Southern & $\mathrm{N}$ & -3.093 & 0.177 & 0.979 & $<0.001$ \\
& & $\mathrm{C}$ & -1.744 & 0.111 & 0.994 & $<0.01$ \\
15 & Northern & $\mathrm{N}$ & -3.105 & 0.272 & 0.984 & $<0.001$ \\
& & $\mathrm{C}$ & -1.106 & 0.124 & 0.971 & $<0.01$ \\
& Southern & $\mathrm{N}$ & -3.061 & 0.265 & 0.988 & $<0.001$ \\
& & $\mathrm{C}$ & -1.658 & 0.164 & 0.986 & $<0.001$ \\
18 & Northern & $\mathrm{N}$ & -3.133 & 0.468 & 0.981 & $<0.001$ \\
& & $\mathrm{C}$ & -1.143 & 0.220 & 0.935 & $<0.01$ \\
& Southern & $\mathrm{N}$ & -2.902 & 0.330 & 0.989 & $<0.001$ \\
20 & Northern & $\mathrm{C}$ & -2.741 & 0.301 & 0.970 & $<0.01$ \\
& & $\mathrm{~N}$ & -3.304 & 0.421 & 0.891 & $<0.01$ \\
22 & Southern & $\mathrm{N}$ & -2.107 & 0.308 & 0.977 & $<0.01$ \\
& & $\mathrm{C}$ & -2.024 & 0.301 & 0.965 & $<0.01$ \\
& & & & & & \\
\hline
\end{tabular}

Table 4. Acartia clausi. Results from ANCOVA comparing $g$ (weight-specific growth rate) and the slopes in Fig. 4 and Table 3. Tests are for homogeneity of slopes within growth phase (effect of temperature), within a given temperature (effect of growth phase) and within temperature and stage (effect of popu- lation). Growth phase is for nauplii or copepodites

\begin{tabular}{|c|c|c|c|c|c|}
\hline & & df & $F$ & $\mathrm{p}$ & Pairwise comparisons \\
\hline \multicolumn{6}{|c|}{ Within growth phase, effect of temperature } \\
\hline \multirow{2}{*}{$\begin{array}{l}\text { Northern } \\
\text { population }\end{array}$} & Nauplii & 3,16 & 13.2 & $<0.001$ & $20^{\circ} \mathrm{C}=18^{\circ} \mathrm{C}>15^{\circ} \mathrm{C}>10^{\circ} \mathrm{C}$ \\
\hline & Copepodites & 3,12 & 10.8 & $<0.001$ & $20^{\circ} \mathrm{C}>18^{\circ} \mathrm{C}>15^{\circ} \mathrm{C}=10^{\circ} \mathrm{C}$ \\
\hline \multirow{2}{*}{$\begin{array}{l}\text { Southern } \\
\text { population }\end{array}$} & Nauplii & 3,16 & 29.3 & $<0.001$ & $22^{\circ} \mathrm{C}>18^{\circ} \mathrm{C}>15^{\circ} \mathrm{C}>10^{\circ} \mathrm{C}$ \\
\hline & Copepodites & 3,12 & 28.1 & $<0.001$ & $22^{\circ} \mathrm{C}=18^{\circ} \mathrm{C}>15^{\circ} \mathrm{C}>10^{\circ} \mathrm{C}$ \\
\hline \multicolumn{6}{|c|}{ Within temperature, effect of growth phase } \\
\hline \multirow{4}{*}{$\begin{array}{l}\text { Northern } \\
\text { population }\end{array}$} & $10^{\circ} \mathrm{C}$ & 1,7 & 8.1 & 0.025 & Nauplii > copepodites \\
\hline & $15^{\circ} \mathrm{C}$ & 1,7 & 47 & $<0.001$ & Nauplii > copepodites \\
\hline & $18^{\circ} \mathrm{C}$ & 1,7 & 27.9 & $<0.001$ & Nauplii > copepodites \\
\hline & $20^{\circ} \mathrm{C}$ & 1,7 & 1.5 & 0.264 & Nauplii = copepodites \\
\hline \multirow{4}{*}{$\begin{array}{l}\text { Southern } \\
\text { population }\end{array}$} & $10^{\circ} \mathrm{C}$ & 1,7 & 17.6 & 0.004 & Nauplii > copepodites \\
\hline & $15^{\circ} \mathrm{C}$ & 1,7 & 27.5 & $<0.001$ & Nauplii > copepodites \\
\hline & $18^{\circ} \mathrm{C}$ & 1,7 & 0.7 & 0.419 & Nauplii $=$ copepodites \\
\hline & $22^{\circ} \mathrm{C}$ & 1,7 & 5.6 & 0.049 & Nauplii > copepodites \\
\hline \multicolumn{6}{|c|}{ Within temperature and stage, effect of population } \\
\hline \multirow[t]{3}{*}{ Nauplii } & $10^{\circ} \mathrm{C}$ & 1,8 & 0.4 & 0.545 & Northern $=$ southern \\
\hline & $15^{\circ} \mathrm{C}$ & 1,8 & 0.1 & 0.786 & Northern $=$ southern \\
\hline & $18^{\circ} \mathrm{C}$ & 1,8 & 15.1 & 0.005 & Northern > southern \\
\hline \multirow[t]{3}{*}{ Copepodites } & $10^{\circ} \mathrm{C}$ & 1,6 & 0.1 & 0.79 & Northern $=$ southern \\
\hline & $15^{\circ} \mathrm{C}$ & 1,6 & 5.8 & 0.052 & Northern $=$ southern \\
\hline & $18^{\circ} \mathrm{C}$ & 1,6 & 3 & 0.133 & Northern $=$ southern \\
\hline
\end{tabular}

a physiological explanation for this pattern is that, in the majority of ectotherm species, an increased temperature would increase rates of growth and differentiation and thereby reduce the size at a given stage due to the imbalance between anabolic and catabolic reactions (Ray 1960). This negative correlation of prosome length with temperature has been found in several copepod species both in the field (e.g. Hirst et al. 1999) and in laboratory studies (e.g. Campbell et al. 2001). In addition to phenotypic plasticity, our study also indicated a latitudinal variation in the prosome length of Acartia clausi. The copepodites and adult females from the southern population were always significantly larger than the north at a given temperature. This conclusion contradicts the general rule about the influence of temperature on the prosome length of copepods. However, the fact that at a given temperature the southern population had slower development rates than the northern population could justify such latitudinal variation.

\section{Growth rates}

At high temperatures, the northern population grew faster than the southern population, and this was due to a faster naupliar development. Growth rates estimated from the general equation of Huntley \& Lopez (1992) were always higher than those observed for copepodites (Fig. 5). At $22^{\circ} \mathrm{C}$, the Huntley \& Lopez model overestimates growth of copepodites of the southern population by $36 \%$. The Huntley \& Lopez model is based on estimates for many species with different tolerances inhabiting regions with variable temperature ranges. As we show here, 2 populations of the same species may respond differently when subjected to the same temperature, depending on genetic differences or different temperature history of the individuals. Acartia clausi from the southern population may be at the thermal limit for growth at $22^{\circ} \mathrm{C}$, whereas the Huntley \& Lopez model should fit species at their thermal optimum, since it is based on field measurements.

Populations exposed to extremes of their natural environmental conditions 

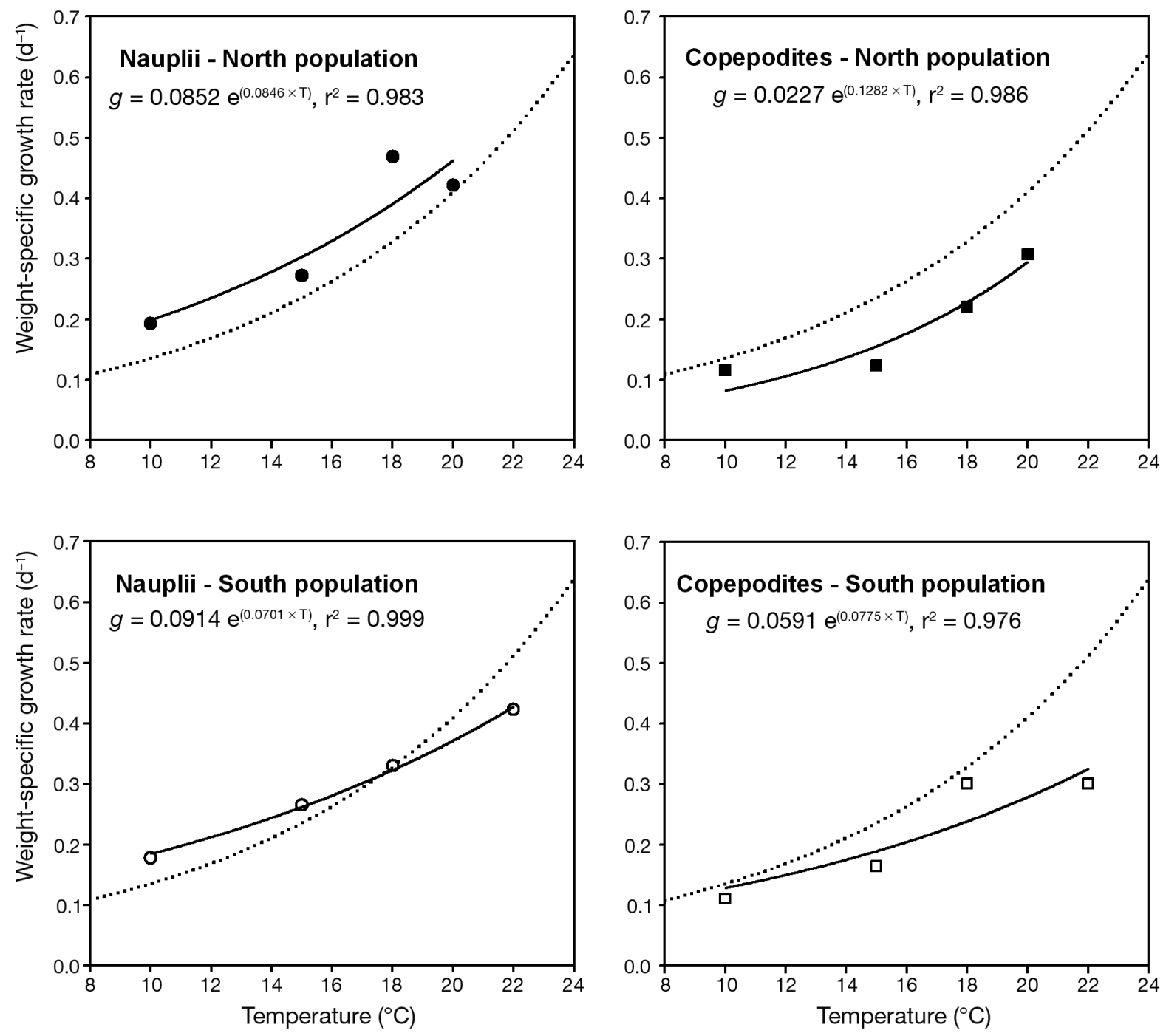

Fig. 5. Acartia clausi. Non-linear regression of the weight-specific growth rate $\left(g, \mathrm{~d}^{-1}\right)$ on temperature $\left(T,{ }^{\circ} \mathrm{C}\right)$ for nauplii and copepodites of both populations. The relationship proposed by Huntley \& Lopez (1992) is indicated by the dashed line

(like our experimental treatments) will not fit the model well. Conversely, population responses to extreme conditions in the field will not be well predicted by the model. We suggest the use of specific growth models instead of general models if estimates of potential growth rates are sought.

In conclusion, this study demonstrates that 2 allopatric populations of Acartia clausi exhibit different development rates when reared at the same temperature. It also indicates the existence of differences in growth rates between populations, particularly when reared at high temperatures, with the northern population (acclimated to cold temperatures) growing faster than the southern population (warm acclimated). Finally, the 2 populations showed different ontogenetic responses to temperature shifts. The northern population had a shorter naupliar phase over all temperatures and increased the growth of copepodites at the highest temperature. This suggests that the 2 populations have developed slightly different survival strategies to adapt to their main area of occurrence.

Acknowledgements. We thank P. Thor, all the staff of Kristineberg Marine Research Station (Sweden) and 4 anonymous reviewers, whose suggestions and comments greatly improved this manuscript. The present work was supported by FCT (Portuguese Foundation for Science and Technology) through a $\mathrm{PhD}$ grant awarded to S.M.L. (SFRH/BD/6873/ 2001). Financial support was allocated by FCT under the Community Support Framework III, Operational Programme Science, Technology and Innovation. 


\section{LITERATURE CITED}

Atkinson D (1994) Temperature and organism size - a biological law for ectotherms? Adv Ecol Res 25:1-58

Berggreen U, Hansen B, Kiørboe T (1988) Food size spectra, ingestion and growth of the copepod Acartia tonsa during development: implications for determination of copepod production. Mar Biol 99:341-352

Bucklin A, Kaartvedt S, Guarnieri M, Goswami U (2000) Population genetics of drifting (Calanus spp.) and resident (Acartia clausi) plankton in Norwegian fjords. J Plankton Res 22:1237-1251

Campbell RG, Wagner MM, Teegarden GJ, Boudreau CA, Durbin EG (2001) Growth and development rates of the copepod Calanus finmarchicus reared in the laboratory. Mar Ecol Prog Ser 221:161-183

Castellani C, Lucas IAN (2003) Seasonal variation in egg morphology and hatching success in the calanoid copepods Temora longicornis, Acartia clausi and Centropages hamatus. J Plankton Res 25:527-537

Castro-Longoria E (2001) Comparative observations on the external morphology of subitaneous and diapause eggs of Acartia species from Southampton water. Crustaceana 74: 225-236

Eriksson S (1973) Abundance and composition of zooplankton on the west coast of Sweden. ZOON 1:113-123

Gaudy R, Cervetto G, Pagano M (2000) Comparison of the metabolism of Acartia clausi and A. tonsa: influence of temperature and salinity. J Exp Mar Biol Ecol 247:51-65

Gómez-Gutiérrez J, Palomares-García R, Silva-Dávilla RD, Carballido-Carranza MA, Martínez-López A (1999) Copepod daily egg production and growth rates in Bahía Magdalena, México. J Plankton Res 21:2227-2244

Gubanova AD, Polikarpov IG, Saburova MA, Prusova IY (2002) Long-term dynamics of mesozooplankton by example of the Copepoda community in Sevastopol Bay (1976 1996). Oceanology 42:512-520

Guillard RRL, Ryther JH (1962) Studies of marine planktonic diatoms. I. Cyclotella nana Husted, and Detonula confervacea (Cleve). Gran. Can J Microbiol 8:229-239

Halsband-Lenk C, Hirche HJ, Carlotti F (2002) Temperature impact on reproduction and development of congener copepod populations. J Exp Mar Biol Ecol 271:121-153

Hay SJ, Kiørboe T, Matthews A (1991) Zooplankton biomass and production in the North Sea during the Autumn Circulation Experiment, October 1987 - March 1988. Cont Shelf Res 11:1453-1476

Hirst AG, Bunker AJ (2003) Growth of marine planktonic copepods: global rates and patterns in relation to chlorophyll $a$, temperature, and body weight. Limnol Oceanogr 48:1988-2010

Hirst AG, Kiørboe T (2002) Mortality of marine planktonic copepods: global rates and patterns. Mar Ecol Prog Ser 230:195-209

Hirst AG, Sheader M, Williams JA (1999) Annual pattern of calanoid copepod abundance, prosome length and minor role in pelagic carbon flux in the Solent, UK. Mar Ecol Prog Ser 177:133-146

Huntley ME, Lopez MDG (1992) Temperature-dependent production of marine copepods: a global synthesis. Am Nat 140:201-242

Klein Breteler WCM, Schogt N (1994) Development of Acartia clausi (Copepoda, Calanoida) cultured at different conditions of temperature and food. Hydrobiologia 292: 469-476

Editorial responsibility: Howard I. Browman (Associate Editorin-Chief), Storebø, Norway
Klein Breteler WCM, Schogt N, Meer JVD (1994) The duration of copepod life stages estimated from stage-frequency data. J Plankton Res 16:1039-1057

Klein Breteler WCM, Gonzalez SR, Schogt N (1995) Development of Pseudocalanus elongatus (Copepoda, Calanoida) cultured at different temperature and food conditions. Mar Ecol Prog Ser 119:99-110

Kouassi E, Pagano M, Saint-Jean L, Arfi R, Bouvy M (2001) Vertical migrations and feeding rhythms of Acartia clausi and Pseudodiaptomus hessei (Copepoda: Calanoida) in a tropical lagoon (Ebrié, Côte d'Ivoire). Estuar Coast Shelf Sci 52:715-728

Landry MR (1975a) Seasonal temperature effects and predicting development rates of marine copepod eggs. Limnol Oceanogr 20:434-440

Landry MR (1975b) The relationship between temperature and the development of life stages of the marine copepod Acartia clausi Giesbr. Limnol Oceanogr 20:854-857

Landry MR (1983) The development of marine calanoid copepods with a comment on the isochronal rule. Limnol Oceanogr 28:614-624

Lindley JA, John AWG, Robins DB (1997). Dry weight, carbon and nitrogen content of some calanoid copepods from the seas around southern Britain in winter. J Mar Biol Assoc UK 77:249-252

Mauchline J (1998) The biology of calanoid copepods. Adv Mar Biol 33:1-707

McLaren IA (1995) Temperature-dependent development in marine copepods: comments on choices of models. J Plankton Res 17:1385-1390

Miller CB, Johnson JK, Heinle DR (1977) Growth rules in the marine copepod genus Acartia. Limnol Oceanogr 22: 326-335

Morgado F, Queiroga H, Melo F, Sorbe JC (2003) Zooplankton abundance in a coastal station off the Ria de Aveiro inlet (north-western Portugal): relations with tidal and day/night cycles. Acta Oecol 24:S175-S181

Pagano M, Kouassi E, Saint-Jean L, Arfi R, Bouvy M (2003) Feeding of Acartia clausi and Pseudodiaptomus hessei (Copepoda: Calanoida) on natural particles in a tropical lagoon (Ebrie, Cote d'Ivoire). Estuar Coast Shelf Sci 56: 433-445

Peterson WT (2001) Patterns in stage duration and development among marine and freshwater calanoid and cyclopoid copepods: a review of rules, physiological constraints, and evolutionary significance. Hydrobiologia 453:91-105

Quevedo M, Gonzalez-Quiros R, Anadon R (1999) Evidence of heavy predation by Noctiluca scintillans on Acartia clausi (Copepoda) eggs off the central Cantabrian coast (NW Spain). Oceanol Acta 22:127-131

Ray C (1960) The application of Bergmann's and Allen's rules to the poikilotherms. J Morphol 106:85-108

Roddie BD, Leakey RJG, Berry AJ (1984) Salinity-temperature tolerance and osmoregulation in Eurytemora affinis (Poppe) (Copepoda : Calanoida) in relation to its distribution in the zooplankton of the upper reaches of the Forth estuary. J Exp Mar Biol Ecol 79:191-211

Strathmann RR (1967) Estimating the organic carbon content of phytoplankton from cell volume or plasma volume. Limnol Oceanogr 12:411-418

Tiselius P, Nielsen TG, Breuel G, Jaanus A, Korshenko A, Witek Z (1991) Copepod egg production in the Skagerrak during SKAGEX, May-June 1990. Mar Biol 111:445-453

Submitted: September 8, 2005; Accepted: March 14, 2006

Proofs received from author(s): September 9, 2006 